\title{
Analysis of Russia and other Countries Economic Parameters and Their Connection with the Development of Science Parks
}

\author{
Anna Vilisova ${ }^{1} \&$ Fu Qiang ${ }^{1}$ \\ ${ }^{1}$ School of Economics \& Business Administration, Chongqing University, Chongqing, China \\ Correspondence: Anna Vilisova, School of Economics \& Business Administration, Chongqing University, room \\ 618, Xuelin Hotel, Campus A, Chongqing University, Chongqing, China. Tel: 86-136-4837-3535. E-mail: \\ weianna@yandex.ru
}

Received: March 3, 2014

Accepted: March 24, 2014

Online Published: May 25, 2014

doi:10.5539/ijef.v6n6p49

URL: http://dx.doi.org/10.5539/ijef.v6n6p49

\begin{abstract}
Economic growth factors in different countries have their own special resources and features due to the difference in development process and environment structure. The authors analyzed the influence of the science parks upon the economic indicators on the example of Russia.

Although there are organizations in Russia created to support the science parks creation, existence and development, there is no efficient and common mechanism to support functioning of the science parks and to make it become oriented at the final result (improving the growth of the country's economy).

The article contains an attempt for the analysis and estimation of the Russia's economy growth possibilities because of the science parks' factor, the main of which is the creation of the comfortable conditions for the establishment and development of start-ups, smooth work of the small innovative and other organizations. The analysis of the Russian economy indices is performed on the basis of the statistics data of the Russian Statistics Bureau published during 1995-2012.

The regressive dependencies, contained in the work and built according to the real statistics data, can provide some data, connected with the extensive component of the science parks factor effect (increase of the number of innovations, created because of the SP factor), such as the maximum possible Russian GDP in 2010, if the science parks supported all small businesses, GDP value expected in 2015 if the situation with the science parks is not changing and if the science parks fully support all small businesses and start-ups etc.
\end{abstract}

Keywords: science park, Russian economy, economic development, small and medium enterprises, small businesses

\section{Introducation}

The economic growth factors attributed to the different countries were always considered as a specific set of mechanisms, being necessary and available at the definite stage of the world economy development. Globalization makes economies be significantly dependent upon each other. However, because of the differences in the economic tradition, development level and structural variety, every country possesses a special set of the resources and factors of the economic growth.

This work contains the analysis of the science parks (SP) influence upon the economic indicators of Russia and other countries. How the science parks' factor can stimulate Russia's economy growth? What are its possibilities and potential usage? How is it possible to use it and why up to now it is not yet included into the system of the mechanisms that could speed up Russia's economic growth? These and other similar questions are raised every time when the subject of the science parks is discussed. Still, researchers and specialists in the different countries are not exactly looking eye to eye when explaining the meaning of the term "Science Park". Still, despite the variety of meanings that exists in relation to this term, the SP factor does exist, and its main component is the creation of the comfortable conditions for the establishment and development of start-ups, smooth work of the small innovative and other organizations. In this respect, the SP factor effect can go, at minimum, in two directions:

- Actual increase of the survived small businesses (extensive effect); 
- Increase of the number of innovations, created because of the SP factor (intensive effect).

Therefore, there are two main directions of the Russian SP factor analysis that could be considered the important ones:

i. Is there a growth potential in Russia, established only on the basis of the quantity (extensive) effect?

ii. What is the growth potential, established on the basis of the SP factor intensive component?

As long ago as the 90s, there were already some attempts to create the science parks in Russia from "below", but the legislative base in the form of the regulatory acts was established only in 2005-2006. The Association of Russian Science Parks, a non-official public organization, the goal of which is to provide the support for the science parks creation, existence and development, was also established. Still, up to now there is no efficient and common mechanism that would support functioning of the science parks and which would be oriented at the final result - indicating the growth of the country's economy.

In our opinion, such mechanism should the state one (possibly, hierarchically established and built into the power vertical). It should contain not only the means of support, but also the means for creation and development of the science parks in the most important industries and areas. For this it is necessary to create specific functional systems, in particular the system that would monitor the conditions and parameters of the SP, the system that would model the variants and possible scenarios of the SP development, the system that would provide SP with the human resources etc.

The article contains an attempt for the analysis and estimate of the Russia's economy growth possibilities because of the SP factor. The analysis of the Russian economy indices is performed on the basis of the statistics data of the Rosstat (Russian Statistics Bureau), that were officially published on its website during 1995-2012. It is necessary to mention though, that not all the data in Rosstat within the mentioned period are presented equally well. This, in its turn, could have an impact upon the accuracy of some estimates.

\section{Last Year Russian Economic Indices}

\subsection{Gross Domestic Product}

One of the most important economic integral indices of any country is the GDP, Gross Domestic Product. Statistics data contain the nominal GDP value (according to the current year prices). But in order to compare the results of several years, usually an inflation coefficient is included (prices increase in relation to the previous year), which is then used for calculating the deflator, a coefficient that specifies the prices change in relation to some definite year (in this research it is 2013). In this case, the actual GDP will show the values that were corrected to the deflator value (see Table 1).

Table 1. Russia's GDP for the period of 1995 to 2012 (in bln Rubles)

\begin{tabular}{cccccc}
\hline Year & Nominal GDP & Inflation & Total Inflation (up to 2013) & Deflator (up to 2013) & Actual GDP (up to 2013) \\
\hline 1995 & 1429 & 1.881 & 21.55206 & 0.04640 & 30798 \\
1996 & 2008 & 1.200 & 11.45777 & 0.08728 & 23005 \\
1997 & 2343 & 1.105 & 9.54814 & 0.10473 & 22367 \\
1998 & 2630 & 1.681 & 8.64085 & 0.11573 & 22722 \\
1999 & 4823 & 1.318 & 5.14030 & 0.19454 & 24793 \\
2000 & 7306 & 1.185 & 3.90008 & 0.25641 & 28494 \\
2001 & 8944 & 1.205 & 3.29121 & 0.30384 & 29437 \\
2002 & 10831 & 1.111 & 2.73129 & 0.36613 & 29583 \\
2003 & 13243 & 1.114 & 2.45841 & 0.40677 & 32557 \\
2004 & 17048 & 1.111 & 2.20683 & 0.45314 & 37622 \\
2005 & 21610 & 1.101 & 1.98634 & 0.50344 & 42925 \\
2006 & 26917 & 1.101 & 1.80413 & 0.55428 & 48562 \\
2007 & 33248 & 1.097 & 1.63863 & 0.61027 & 54481 \\
2008 & 41277 & 1.124 & 1.49373 & 0.66946 & 61657 \\
2009 & 38807 & 1.086 & 1.32895 & 0.75248 & 51572 \\
2010 & 45173 & 1.085 & 1.22371 & 0.81719 & 55278 \\
2011 & 54586 & 1.060 & 1.12784 & 0.88665 & 61564 \\
2012 & 56769 & 1.064 & 1.06400 & 0.93985 & 60403 \\
2013 & & 1 & 1 & 1 & \\
\hline
\end{tabular}


Figure 2 contains the chart of the actual GDP changing (g) according to years $(\mathrm{t})$ and its linear approximation (regression equation) for the period from 1997 to 2012. The regression equation is highly adequate to the values in column 6 of the Table $1\left(R^{2}=0.940\right)$ and presented further:

$$
g=-6121618.131+3074.785 t
$$

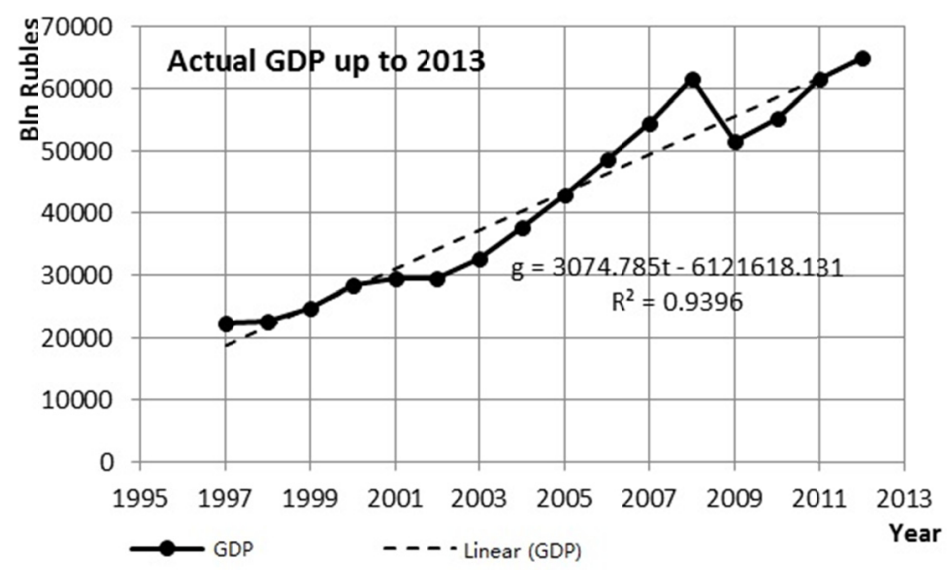

Figure 2. Russia's actual GDP

GDP's 2009 decrease was caused by the world economy crisis occurred during this period. Thus, the 20 -year average annual rate of the Russian GDP growth amounts approximately for 3000 billion Rubles or 100 billion US Dollars approximately.

\subsection{Dynamics of the Industry and Entrepreneurial Activity Growth}

Activity of the small businesses and businesses in general mainly contribute to the country's GDP. Let's analyse statistics data of the organizations belonging to all industries of the Russian economy, including small businesses. For the purposes of the research, we would be using two business indices: the number of the businesses and their turnover.

During the period of active privatization, the industry was quickly turning private and the number of the private companies was growing rapidly. Figure 3 contains changes in the business numbers that went up during those and next years. It is possible to see that the main part of the businesses consists of the private enterprises.

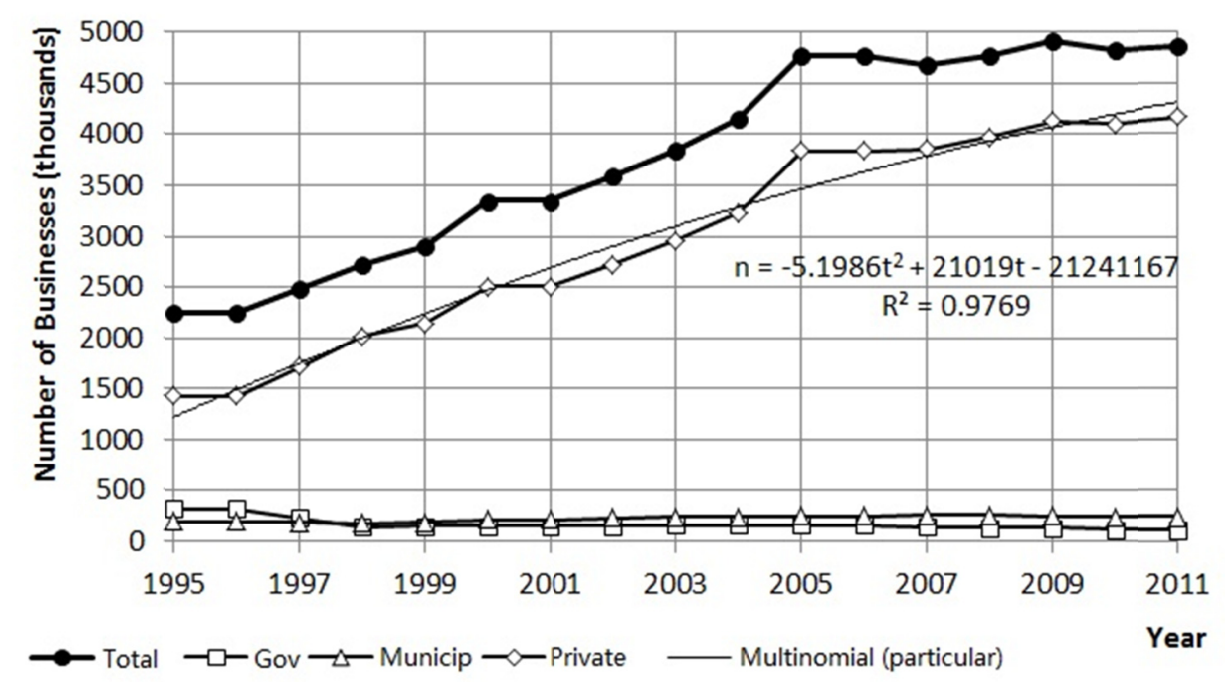

Figure 3. Number of business with different proprietorship form 
Yearly changes $(t)$ of the small businesses number $(n)$, which comprised the significant share of the private companies, is going to be approximated by the $2^{\text {nd }}$ class polynomial regression:

$$
n=-21241167+21019 t-5.1986 t^{2}
$$

The equation (2) has a high adequacy level, as $\mathrm{R}^{2}=0.9777$.

Equation (2) reflects the fact that the growth rates of the small businesses number comprise a bit more than 20 thousand companies per year. During all these years the total increase of the companies' number was mainly caused by the establishment of many small private businesses. However, small private companies, especially during 90s, did not contribute significantly into the general turnover, and accordingly into the country's GDP. In general, it was the large state or municipal companies which provided the turnover. The actual turnover (taking the deflator into account) of the companies with different proprietorship forms (calculated according to Rosstat data, which is available for the analysis) is provided on Figure 4.

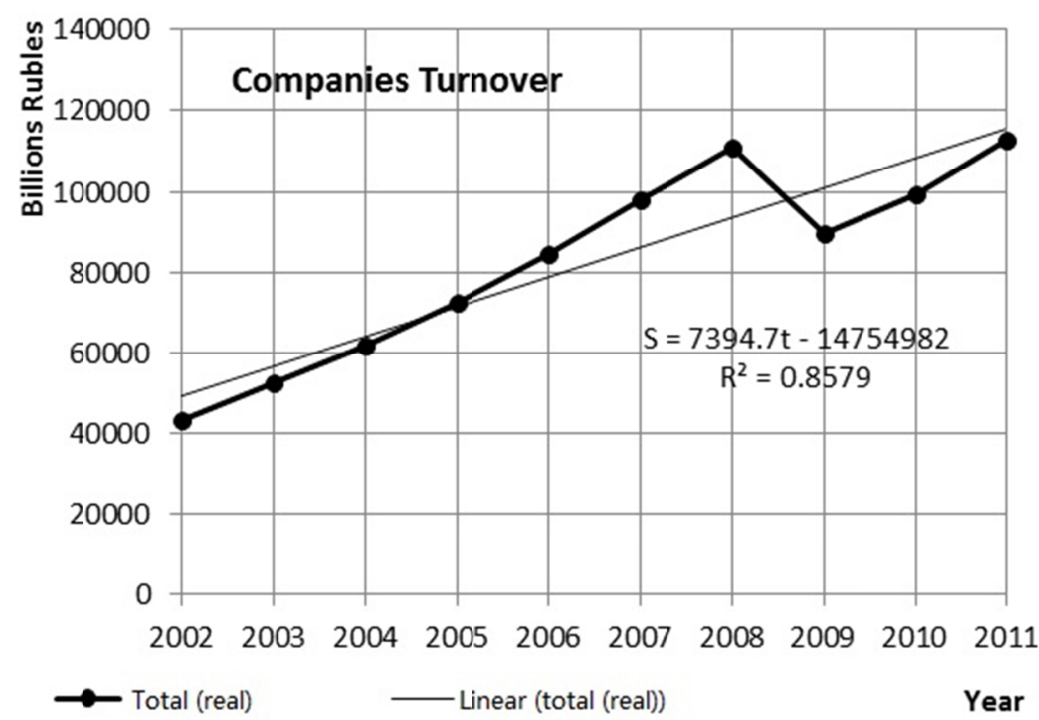

Figure 4. Turnover of the companies with different proprietorship forms

As it can be seen from the GDP dynamics (see figure 2) and companies' turnover (see figure 4), the nature of their changes is similar, therefore these values should possess a close correlational connection. It is quite easy to show this connection as a regressive dependence, which would allow obtaining a GDP estimate when using the companies' turnover (see figure 2). The input (independent) value is the companies' turnover $(S)$, with the output (dependent) value being the GDP $(g)$. Thus, the established linear regressive model is:

$$
g=b_{0}+b_{1} S=18497+0.35674 S
$$

The equation (3) has a high adequacy level as $\mathrm{R}^{2}=0.858$.

The built dependence (3) does not contain anymore the time factor $(t)$, but establishes the connection of the GDP volume with the annual turnover of all companies. It is necessary to mention though that this dependence is specific per each country, it reflects the peculiarities of the country's economic condition and the state of the economy. The linear nature of this dependence states the fact that during all 10 years that are available for the research, the GDP's turnover share has not changed, comprising one third of the turnover.

As one of the main functions of the science parks is to support the whole process of establishing small businesses, then in the regression models chain under analysis it is necessary to consider the turnover of the small enterprises, as a part of all totality of the companies. The available statistics data showing the turnover of the small businesses is provided on figure 5, which also contains the turnover of all companies for the comparison purposes.

Here (please see the right adjoining scale) it is also possible to see the relative share of the small businesses turnover, being also the part of the total turnover of all companies. Within the period available for the analysis, the average value of this share amounted to $15.6 \%$. It could be possible to build the annual share growth model, 
but the crisis fluctuations of the turnover and the little interval value of the research do not allow obtaining the reasonable degree of adequacy for the linear regressive model (it comprises only $\mathrm{R}^{2}=0.007$ ). Therefore, when building future equations, we shall consider the small businesses relative share value as a constant $(d=0.156)$. In this case the absolute value of this share (turnover of all small businesses) can be presented as:

$$
S_{\text {small businesses }}=d S
$$

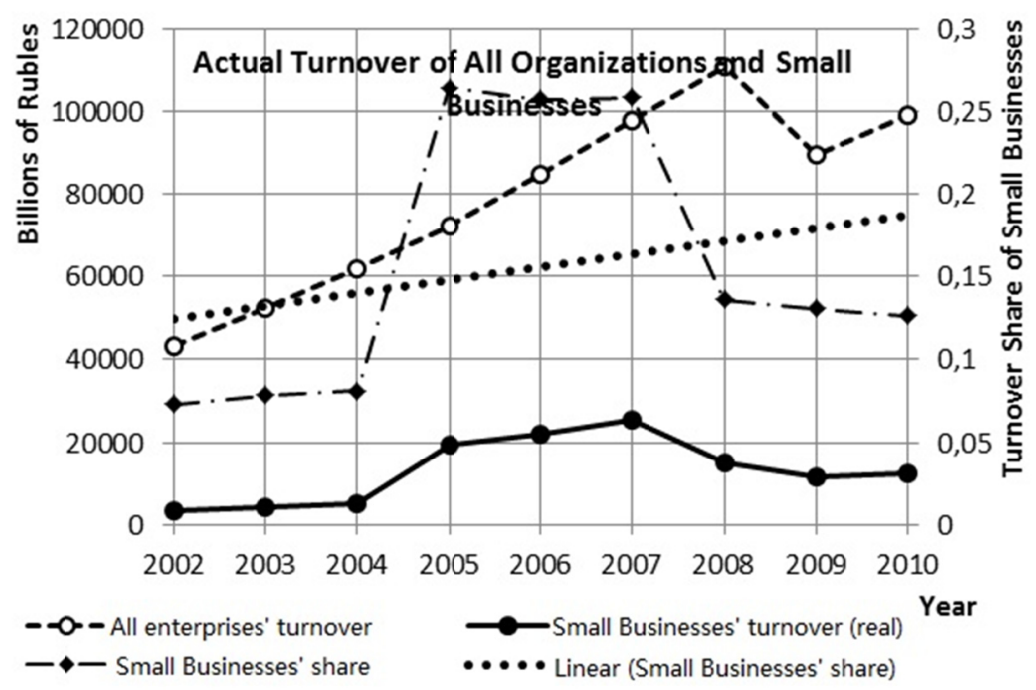

Figure 5. Small businesses turnover share

\subsection{Peculiarities and Main Parameters of Small Businesses in Russia}

Small businesses are the alliances of the entrepreneurs, with just several employees and small turnover. Rosstat's statistics data define the following classes of the small businesses:

- Private entrepreneurs (number of employees is less than 5 people);

- Micro organizations (number of employees is less than 16 people or turnover is less than 60 mln Rubles);

- Small businesses (number of employees is from 16 to 100 people or turnover is from 60 to $400 \mathrm{mln}$ Rubles);

- Middle companies (number of employees is from 100 to 500 people or turnover exceeds $400 \mathrm{mln}$ Rubles);

Some 2011 statistics data for this class of businesses is shown in Table 2 and Figure 6.

Table 2. Statistical characteristics of small and middle businesses (according to 2011 data)

\begin{tabular}{|c|c|c|c|c|c|}
\hline Definition & $\begin{array}{l}\text { Private } \\
\text { Entrepreneurs }\end{array}$ & $\begin{array}{l}\text { Micro } \\
\text { organizations }\end{array}$ & $\begin{array}{l}\text { Small } \\
\text { Businesses }\end{array}$ & $\begin{array}{l}\text { Middle } \\
\text { Businesses }\end{array}$ & Total \\
\hline Number of registered organizations, thousands & 2900 & 1400 & 229 & 25.7 & 4554.7 \\
\hline Number of active organizations, thousands & 1900 & 1000 & 227 & 25.7 & 3152.7 \\
\hline Number of employees, mln people & 5.3 & 3.9 & 7.2 & 2.6 & 19 \\
\hline Income, bln Rubles & 4500 & 5700 & 13300 & 7300 & 30800 \\
\hline $\begin{array}{l}\text { Average income of the active organizations, mln } \\
\text { Rubles }\end{array}$ & 2.4 & 5.7 & 58.6 & 284 & 9.8 \\
\hline $\begin{array}{l}\text { Average number of employees (in active } \\
\text { organizations), people }\end{array}$ & 3 & 4 & 32 & 101 & 6 \\
\hline $\begin{array}{l}\text { Share of active organizations among all } \\
\text { registered, \% }\end{array}$ & 66 & 71 & 99 & 100 & 69 \\
\hline $\begin{array}{l}\text { Share of active organizations among all classes or } \\
\text { organizations, } \%\end{array}$ & 60 & 32 & 7 & 1 & 100 \\
\hline Share of income, $\%$ & 15 & 19 & 43 & 24 & 100 \\
\hline
\end{tabular}




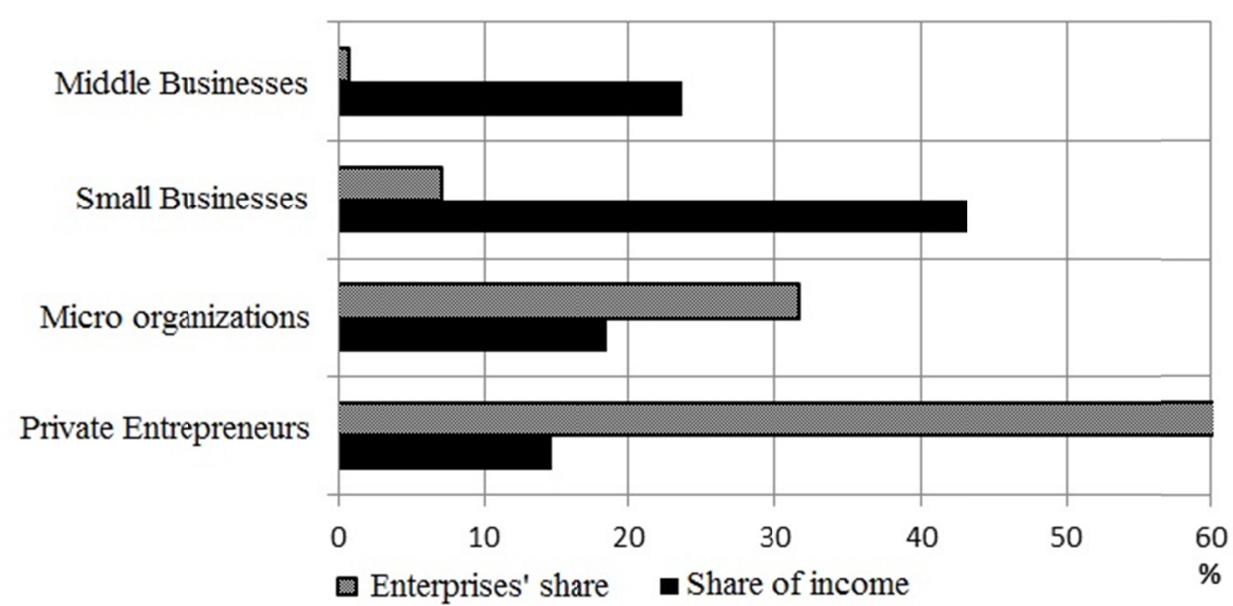

Figure 6. Distribution of the income volume among the business classes and their share in the total number of businesses (2011)

The important characteristic, which is necessary for the further analysis, is the income's average volume (IAV) per one business $\left(\mathrm{S}_{1 \text { small business }}\right)$. According to 2002-2010 Rosstat statistics data, it is possible to deduce that IAV depends significantly on the country's economic situation and the nature of its variation is similar to the "Small Business Share" indicator, shown on figure 5 (i.e. it is quite unstable). Therefore, when making further calculations, we shall use only IAV for the period of the research mentioned above, which is:

$$
S_{\text {Ismall business }}=3.5 \mathrm{~m} \ln \text { Rubles }
$$

As it can be seen from the chart 2, 2011 IAV for the average and small businesses amounted to:

$$
S_{\text {Ismall business_2011 }}=9.8 \mathrm{mln} \text { Rubles }
$$

Still, it is necessary to mention that as a rule, the significant majority of the companies, comprising science parks residents, is not average businesses, this is why the IAV value for all companies, except average ones, shall be:

$$
S_{\text {Ismall business_2011 }}=7.5 \mathrm{mln} \text { Rubles }
$$

The income values, mentioned above, define the IAV variation ranges for the small businesses. Despite the fact that the definition of the company income (being a monetary value, received from selling the goods and / or services) differs from the definition of the turnover (being a monetary value of the shipped goods and performed services volume), we shall consider them equivalent within the framework of this research. The reason for the above is that we investigate the processes, occurring during several years, thus the time period levels these two parameters.

\subsection{Some Economic Indicators of other Countries Occurred within Last Years}

The share of small businesses in the economies of other countries differs greatly from their share in Russia's economy. Thus, in the USA economy the number of small businesses (with the number of employees not more than 19 people) constitutes around $85 \%$. This proves the fact that there is practically no GDP growth potential because of the small businesses survival rate in the USA.

The average turnover of the micro and small businesses in the European Union constitutes practically the same value as in Russia (see Table 2). But at the same time, the share of small businesses in the total number of the European companies (87\%), as in the USA, is significantly larger than in Russia, where it comprises $15,6 \%$.

In China, the small and average business sector owns more than $80 \%$ of the new Chinese products, being responsible for practically $60 \%$ of the GDP and $74,7 \%$ of the industrial production added value. At that, practically $99 \%$ of the companies can be considered small businesses with less than 100 employees, and only $0,6 \%$ are defined as the average companies with the number of employees varying from 101 to 999 people. 


\section{Small Businesses Share In The Total Number of Companies}

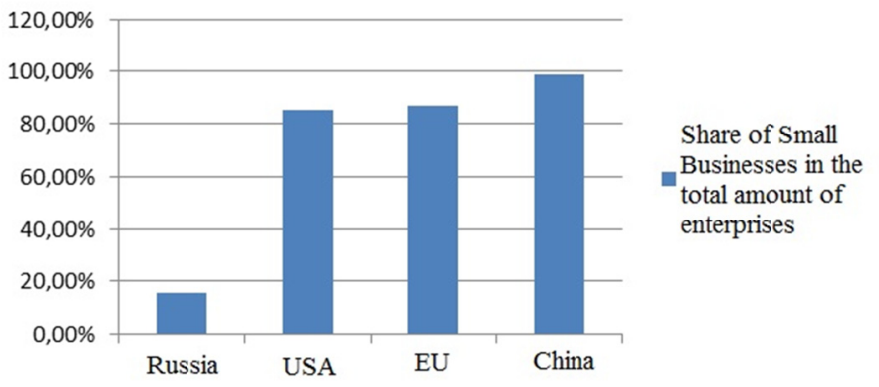

Figure 7. Share of small businesses in the total number of the companies per country and region.

As the general tendency in many foreign countries (China, European Union, USA etc.) is such that the significant share of the GDP is provided by the small businesses, their initial chances for the science park contribution into the country's GDP growth are much higher than with the other countries, as their growth potential because of the small businesses contribution is already used up. For these countries, one of the important growth factors (if not the only one) shall be the innovational development, where science parks can play a significant role. But in Russia, except innovational growth component, there is still a big potential of the GDP growth because of the small businesses number increase.

\section{Conclusions}

The analysis, performed on the basis of Rosstat's official statistics data showed the following results:

- During the main period of research (2002-2011), the GDP growth rate because of the SP factor's extensive effect, i.e. because of increasing the number of the survived small businesses (from the total number of the registered ones), does not depend on the year, which allows considering the effect as the average value of the GDP increase rate irrespective of the year under the research.

- Innovational component of SP factor and its relation to Russia was not researched in this work, but the data provided for other countries prove the fact that the extensive part of the SP factor effect is already absent there, and they are left only with the intensive component growth, i.e., developing the innovational growth. Generally, science parks in Russia are quite underdeveloped, the intensive component is presented mainly by the Skolkovo project, which, however, cannot create the necessary "critical mass" in order to feel the innovational effect of the SP factor. At that it is quite possible that Russia can try to obtain this effect using the simple extensive component of the SP factor that would not stimulate the innovational component, leading, as a result, to a further technological lag in comparison with other countries.

The regressive dependencies, contained in the work and built according to the real statistics data, can provide answers to some specific questions, connected with the extensive component of the SP factor effect, for example:

- What could be the maximum possible Russian GDP in 2010, if the science parks supported all small businesses, provided that without them the rate of the survived businesses constitutes $25 \%$ and the actual GDP amounted to 61778 billion Rubles (according to the average tendency data)? Answer: 91593 billion Rubles, which constitutes around $147 \%$ off the actual one.

- What GDP value should Russia be expecting in 2015 (1) if the situation with the science parks is not changing and (2) if the science parks fully support all small businesses and start-ups? Answer: (1) in 2015, without science parks, Russian GDP will constitute 74074 billion Rubles and (2) provided that science parks fully support all kinds of businesses - 108592 billion Rubles, which also shall constitute around 147\% off the expected non-SP amount.

- What would be the Russian GDP growth in relation to the previous question, provided that the science park sphere shall be developed to such a degree that the $25 \%$ share of the survived small businesses increases further to $15 \%$ (i.e. constitutes $40 \%$ in total)? Answer: the GDP growth rate shall constitute $9 \%$ (see $k$ value, which equals 0.25 and $\beta$ equaling 0.15), thus constituting 80740 billion Rubles, i.e. $109 \%$ off the GDP forecast for 2015, being 74074 billion Rubles. The net GDP growth shall constitute 6667 billion Rubles that would allow planning budgetary means aiming at the development of the science parks. 


\section{References}

How Small Business Is Supported In China. (2014). Retrieved from https://www.google.ru/url?sa=t\&rct=j\&q=\&esrc=s\&source=web\&cd=2\&cad=rja\&ved=0CDMQFjAB\&url $=$ http $\% 3 \mathrm{~A} \% 2 \mathrm{~F} \% 2 \mathrm{Fwww} . g o m e l-a g e n c y . o r g \% 2 \mathrm{Fuserfiles} \% 2 \mathrm{Ffile} \% 2 \mathrm{Fkak}$ podderzhivayut_malyy_biznes_v _kitae.doc\&ei=feDHUtb8MI2Q4ATu-YHoAw\&usg=AFQjCNH7pfr9aaH0Q3Q6sD5ddG8OVnfeRg\&bvm $=$ bv. 58187178 , d.bGE

Pinkovetskaya, Y. (2012). Concept of the development strategy for the small businesses in the regions of Russian federation. Economic Investigations, 3(12).

Russian Federation. (2010). Main directions of the Russian Federation policy in the innovation system development for the period till 2010. Ratified by Russian Federation Government on the $5^{\text {th }}$ of august 2005 N 2473п-П7.

Shpynova, A. (2009). Crediting small and average businesses-Foreign and Russian experiences. Polpred Reference Books Printing House, 156.

Skolkovo Project. (2014). Retrieved from http://www.skolkovo.ru

Small Businesses In The World. (2014). Retrieved from http://ru.exrus.eu/\%D0\%9C\%D0\%B0\%D0\%BB\%D1\%8B\%D0\%B5-\%D0\%BF\%D1\%80\%D0\%B5\%D0\% B4\%D0\%BF\%D1\%80\%D0\%B8\%D1\%8F\%D1\%82\%D0\%B8\%D1\%8F-\%D0\%B2-\%D0\%BC\%D0\%B8\% D1\%80\%D0\%B5-id4dcfac366ccc19400f000022

State Statistics Federal Service. (2014). Retrieved from http://gks.ru/wps/wcm/connect/rosstat/rosstatsite/main/ Vilisova, A. V., \& Qiang, F. (2013). The estimation model of the technology parks' potential.

Web. (2005). The small business economy: A report to the president (p. 222). Washington: United States Government Printing Office. Retrieved from http://www.sba.gov/advo/research/sb_econ2005.pdf

\section{Copyrights}

Copyright for this article is retained by the author(s), with first publication rights granted to the journal.

This is an open-access article distributed under the terms and conditions of the Creative Commons Attribution license (http://creativecommons.org/licenses/by/3.0/). 